Bente Rigmor Walgermo

Universitetet i Stavanger

Per Henning Uppstad

Universitetet i Stavanger

Kjersti Lundetrce

Universitetet i Stavanger

Finn Egil Tønnessen

Universitetet i Stavanger

Oddny Judith Solheim

Universitetet i Stavanger

DOI: http://dx.doi.org/10.5617/adno.6499

\title{
Kartleggingsprøver i lesing - tid for nytenking?
}

\section{Sammendrag}

Som en del av det Nasjonale kvalitetsvurderingssystemet for grunnopplæringen (NKVS) i norsk utdanning har vi i dag forskjellige leseprøver med ulikt formål og utforming for bruk i det 13-årige skoleløpet. I denne artikkelen tegner vi opp en historisk bakgrunn for innføringen av kartleggingsprøvene $i$ lesing $i$ begynneropplceringen, og peker på flere forhold som kaller på en nytenking av dette prøvekonseptet. I artikkelen viser vi ved hjelp av data fra en longitudinell studie hvordan en kort oppgave gjennomført i slutten av første klasse predikerer vansker med leseforståelse i 3. klasse. Med utgangspunkt i disse resultatene drøfter vi kimen til et mulig nytt prøvekonsept med potensiale for a) bedre samsvar mellom teori om lesing og måling av lesing, b) longitudinell prediksjon, og c) en prøve som kan gjennomføres på kortere tid med forbedret pedagogisk potensiale. Sentralt i dette forslaget står tanken om en kort inngangsprøve som oppfyller prøvens primcere formål om å identifisere de elevene som står i fare for å utvikle vansker med lesing, fulgt av en utforskende del gjennomført en-tilen som gir lareren informasjon om hvordan vansken arter seg.

Nøkkelord: kartleggingsprøver i lesing, longitudinell prediksjon, tidlig innsats, dysleksi, lese- og skrivevansker, intensiv opplaring. 


\title{
Is it time to rethink screening tests for Reading?
}

\begin{abstract}
As part of the national quality assessment system in education, Norwegian schools use a variety of reading test with different purposes and designs. In this study we initially provide a historical background regarding the development and implementation of the first-grade screening tests for reading. Within this historical context, we point to the need for rethinking the overall design and philosophy of these tests. Using longitudinal study data, we empirically document how a short group-administered assessment task at the end of first grade predicts difficulties in reading comprehension at the end of third grade. Based on these results we discuss the development of a new design with potentially a) better concurrence of reading theory and reading measures, $b$ ) longitudinal prediction, c) a shorter test with better pedagogical potential. Central to this idea is a short initial task that can fulfil the primary purpose of the screening, followed by an explorative, observational aspect, implemented in a one-to-one manner, that would provide greater information regarding the nature of the difficulty.
\end{abstract}

Keywords: screening tests for reading, longitudinal prediction, early efforts, dyslexia, reading and writing difficulties, special education

\section{Introduksjon}

Det nasjonale kvalitetsvurderingssystemet for grunnopplæringen inkluderer i dag forskjellige leseprøver for bruk i det 10-årige skoleløpet: Kartleggingsprøver i lesing (1.-3. trinn), Nasjonale prøver i lesing (5., 8., og 9. trinn) og Læringsstøttende prøver i lesing (mellomtrinnet). De obligatoriske prøvene - kartleggingsprøvene og nasjonale prøver - har vært sentrale i norsk utdanningspolitikk og styring av norsk utdanning siden tidlig 2000-tallet.

I denne artikkelen gir vi en historisk oversikt over formål og utforming av kartleggingsprøven i lesing på 1. trinn. Vi løfter videre fram noen av utfordringene med dagens prøve, og undersøker deretter hvorvidt delprøvene som inngår i dagens kartleggingsprøve på 1. trinn er nødvendige for å oppfylle prøvens primære formål: å finne fram til elever som trenger ekstra hjelp de første årene på skolen. I forlengelse av denne analysen diskuterer vi hvordan et alternativt prøvekonsept, men med samme primære formål som dagens prøver, kan se ut.

\section{Bakgrunn for prøvenes formål og utforming}

Siden arbeidet med kartleggingsprøvene startet, har formålet vært å finne frem til de elevene som trenger ekstra støtte i leseutviklingen. Arbeidet med å utvikle 
kartleggingsprøver i lesing begynte tidlig på 90-tallet og var basert på behov blant lærere for en screeningprøve som kunne administreres på klassenivå for å undersøke så mange sider som mulig av elevenes leseferdighet. Formålet var å avdekke eventuelle vansker, uten å gå dybden slik diagnostiske prøver gjør (Solheim \& Tønnessen, 1998).

Kartleggingsprøvene har siden starten hatt et spesifikt formål og skiller seg derfor også i dag fra nasjonale prøver i lesing både når det gjelder formål og utforming. Formålet med nasjonale prøver er å gi lærere informasjon som kan danne grunnlag for underveisvurdering, samt gi skoleledere, skoleeiere og regionale myndigheter informasjon som kan tjene som grunnlag for forbedringsog utviklingsarbeid i skolen. De nasjonale prøvene er dermed utformet på en måte som gir informasjon om leseferdigheten til elever på alle ferdighetsnivå. Kartleggingsprøvene,derimot, er først og fremst et verktøy for å finne frem til de elevene som trenger ekstra oppfølging i leseopplæringen:

Formålet med kartleggingsprøvene er å hjelpe skolene og lærerne med å finne de elevene som trenger ekstra hjelp og støtte i leseutviklingen i løpet av de første skoleårene (Utdanningsdirektoratet, 2018).

Kartleggingsprøvene er derfor utformet for å gi mest mulig informasjon om leseferdigheten til de lavest presterende elevene.

I perioden 1992 til 1995 ble de tre første kartleggingsprøvene i lesing utviklet for 1., 2., og 6., trinn. I denne perioden var kartleggingsprøvene frivillige. Prøvene ble så godt mottatt at det umiddelbart ble satt i gang arbeid med å utvikle kartleggingsprøver i lesing også for 5. og 9. trinn. I 1997 fikk vi skolestart for 6-åringer, og med denne utvidelsen av den obligatoriske skolegangen fra 9 til 10 år kom store endringer i begynneropplæringen. Det første skoleåret skulle være et skoleforberedende år og formell opplæring skulle først begynne i 2. klasse. Det ble derfor nødvendig å vurdere kartleggingsmateriellet i forhold til når det skulle brukes i det nye skoleløpet. Reform 97 vektla at man først i andre klasse skulle jobbe systematisk med bokstavinnlæring og la således sterke føringer for at det i 2000 ble innført obligatoriske kartleggingsprøver først etter 2. trinn i tillegg til på 7. trinn, mens 1. trinn-prøven forble frivillig frem til 2009. Kartleggingsprøven for 3. trinn ble først obligatorisk fra 2010.

Det såkalte Pisa-sjokket i 2001 fikk også konsekvenser for begynneropplæringen. Sjokket bestod i at norske 15-åringer skåret om lag på OECD-gjennomsnittet i lesing, mens selvoppfatningen blant norske skolepolitikere var at vi hadde en svært god skole. Som en konsekvens av det læringstrykket og den re-orienteringen som blant annet oppstod i kjølvannet av Pisa-resultatene fra 2001 blir den første formelle lese- og skriveopplæringen i de fleste norske skoler i dag gjennomført i løpet av 1. klasse. Gabrielsen og Lundetræ (2017) påpeker at innføringen av obligatoriske kartleggingsprøver i 
første klasse i 2009 derfor må ses som "et tydelig signal om å introdusere bokstavene og arbeide systematisk med lesing og skriving fra første trinn.” (Gabrielsen \& Lundetræ, 2017, s. 209).

Som vist over har synet på hva første klasse skal inneholde endret seg siden kartleggingsprøvene først ble tatt i bruk og frem til i dag. Hele tiden har man likevel vært bevisst den store variasjonen i ferdighet som finnes i første klasse. Eksempelvis ble elevers ulike utgangspunkt i første generasjon kartleggingsprøver brukt som begrunnelse for at det var lite meningsfullt å lage en normalfordelt prøve for denne aldersgruppen:

Leseferdigheten er under utvikling i 1. og 2. klasse, og det gir liten mening å normere prøvene gjennom en statistisk fordeling av resultatene på en Gauss-kurve. Man vil i så tilfelle få et tilsynelatende nøyaktig mål på en meget ustabil ferdighet. Siktemålet ble derfor at prøvene i de to første klassene ikke skulle ha som mål å fingradere ferdighetene hos de flinkeste, men først og fremst være til hjelp med å finne de 15 20\% svakeste leserne (Solheim \& Tønnessen, 1998).

Konklusjonen ble dermed at prøven på første og andre trinn ikke skulle ha som formål å gi fingradert informasjon om alle, men bidra til å finne de svakeste leserne. Her ble det satt en bekymringsgrense som inkluderte de $20 \%$ lavest presterende elevene. Grensen var basert på pedagogiske erfaringer og forskning som tilsier at cirka $20 \%$ av elevgruppen er spesielt utsatt for å utvikle lesevansker av ulik art (Shaywitz, Fletcher, Holahan \& Shaywitz, 1992; Tønnessen \& Solheim, 1998). Å lage en prøve som målte aspekter ved lesing mest nøyaktig blant de svakeste elevene, innebar derfor at prøven ville få takeffekt, altså at mange elever ville få alt riktig på delprøvene og at de beste leserne ikke ville få vist hvor gode de var. En årsak til denne utformingen var ønsket om at prøven ikke skulle være for tidkrevende å gjennomføre, i og med at en prøve som måler hele ferdigheten nødvendigvis måtte være mer omfattende. I tillegg var det et uttalt mål at prøven skulle bidra til opplevelse av mestring for de svakeste leserne. $\AA$ fokusere på identifikasjon av de svakeste elevene i en prøve med tak-effekt la til rette for gjennomføring av et større antall delprøver, men med færre oppgaveledd på hver delprøve, og dermed en prøve som var mulig å gjennomføre i løpet av en skoletime.

I tillegg til å fungere som et verktøy for å fange opp elever som trenger ekstra støtte i leseutviklingen, har intensjonen vært at kartleggingsprøvene skulle legge føringer for praksis. I sin doktorgradsavhandling, som er basert på arbeidet med å lage de første kartleggingsprøvene i lesing for 1. og 2.trinn, beskriver Liv Engen (1999) at det var et mål at prøvene skulle fungere veiledende i forhold til god leseopplæring i klasserommet:

En ønsket at de skulle kunne bidra til å styre lærernes oppmerksomhet mot sentrale sider ved leseprosessen, gi dem kunnskap om hvilke ferdigheter det var viktig å observere og gi råd om hvordan dette kunne gjøres. (...) En antok følgelig at det som 
ble vektlagt i prøvene på sikt også ville kunne påvirke leseopplæringen generelt, og at prøvene dermed ville være av indirekte betydning for undervisningsplanlegging og i det forebyggende arbeidet. (Engen, 1999, s. 31)

Prøvene skulle slik bidra med informasjon for tilrettelegging og gjennomføring av begynneropplæring og spesialundervisning samt oppleves nyttige i skolens vurdering av om videre henvisning til PPT var nødvendig (Solheim \& Tønnessen, 1998). Med unntak av et knippe mastergradsoppgaver (se for eksempel Barkved, 2012) som dokumenterer at prøvene fyller et behov, har vi ikke empiriske undersøkelser som på noen grundigere måter beskriver hvordan innføringen av kartleggingsprøver i lesing har endret praksis og kunnskap i skolen. I denne artikkelen setter vi frem en påstand om at det er tid for å tenke nytt, som også innebærer en bevissthet om at prøvene har hatt uheldige innvirkninger på praksis. Kartleggingsprøvene - slik de har vært utformet - kan likevel sies å ha formidlet og implementert en sterk konkretisering av teoretiske perspektiver som var rådende i en viss tid og i en viss tradisjon.

\section{Teoretisk forankring}

Arbeidet med å utvikle kartleggingsprøven i lesing på første trinn ble hovedsakelig forankret i forskning på begynneropplæring og lesevansker (Engen, 1999). Ettersom det var et uttalt mål å gi informasjon som kunne støtte lærernes undervisning, valgte man å inkludere kartlegging av aspekter ved leseprosessen som en rekke studier hadde vist var sentrale for å lære å lese, samt at vansker med disse ferdighetene predikerte vansker med lesing (Schneider, Roth \& Ennemoser, 2000). Basert på Høien og Lundberg (1991) ble et prosessanalytisk syn på lesing forsøkt ivaretatt ved å la ulike delprøver representere ulike komponenter i leseprosessen (Engen, 1999). I tillegg til kartlegging av elevenes leseferdighet valgte man derfor å inkludere delprøver som kartla bokstavkunnskap og fonemisk bevissthet. Formålet med disse delprøvene var å synliggjøre områder man mente var viktig for lærere å fokusere på i begynneropplæringen, ut fra en tanke om at tiltakene også kunne rettes direkte inn mot disse. Kartleggingsprøven i lesing på første trinn kan slik sies å representere et syn på lesing som bestående av delprosesser hvor lesing tenkes å forutsette en rekke kunnskaper og ferdigheter (Høien \& Lundberg, 1991; Høien, 2012; Engen, 1999). Som en fortsettelse av dette synet, inneholder dagens kartleggingsprøve for første klasse følgende seks delprøver: bokstavkunnskap, fonologisk analyse, fonologisk syntese, staving av enkle lydrette ord (enstavelsesord), deretter en delprøve som måler ordlesing og til slutt en prøve som måler elevens evne til å lese og forstå enkle setninger. Prøven gjennomføres $i$ et fastsatt tidsvindu i mars-april med en tidsramme på 60 minutter. 


\section{Utfordringer med dagens kartleggingsprøver}

Til historikken for det 20-årige designet for kartleggingsprøvene hører også erfaringene med bruken av prøvene og særlig utfordringer knyttet til gjennomføring av prøvene i klasserommet, prøvens innhold og lærernes tolking av testresultatene. Oppsummert kan utfordringene knyttes til: 1) prøvenes omfang, 2) utilsiktede konsekvenser for undervisningspraksis, 3) feil bruk av prøveresultater 4) ulik progresjon i begynneropplæringen og 5) høy terskel for bruk av prøveresultater

En klar utfordring med kartleggingsprøvene er omfanget av prøven, og dermed også tidsbruken. Prøven kan være spesielt krevende å gjennomføre for de elevene som strever mest - 60 minutter er lenge å jobbe med noe man ikke opplever å mestre. Det er også uheldig at alle elevene gjennomfører en omfattende prøve som er laget for de få - altså for å få informasjon på områder som er mest relevante for elever som sliter med lesing. Gjennomføring i hel klasse gjør det også problematisk å danne et nyansert bilde av hvorfor de svakeste leserne strever siden grunnene til at en elev ikke svarer på en oppgave eller svarer feil kan være svært forskjellige. Gjennomføringen i gruppe gir dermed læreren liten mulighet for å kunne observere hvordan de svakeste leserne løser oppgavene. Med andre ord kan prøven sies å være for omfattende både for de sterkeste og de svakeste leserne, men med ulik begrunnelse. I et nytt prøvedesign bør prøven være kortere for de den ikke er ment for, samt gi mer informasjon og en bedre mestringsopplevelse for de den er ment for.

En andre utfordring er at utformingen av prøvene har gitt utilsiktede konsekvenser for undervisningspraksis. Særlig gjelder dette at prøvene bygger på en teori som sterkt vektlegger trening på fonologiske ferdigheter isolert sett, mens senere forskning har vist at forventningene til dette har vært for høye (Gustafson, Samuelsson \& Rönnberg, 2000). Studier har derimot vist at kombinerte tiltak på både helheter og deler, altså på både avkoding og forståelse, har best effekt (National Reading Panel, 2000; Suggate, 2010; Ehri mfl., 2001; Scammacca mfl., 2007). Selv om intensjonen til kartleggingsprøvene opprinnelig var å legge føringer for god klasseromspraksis (Engen, 1999), viser erfaring at lærere ofte har begrenset kunnskap om hva delprøvene måler, hvordan delferdigheten inngår i den større helheten (leseferdighet) og hvordan undervisningen kan innrettes i lys av prøveresultatene. Eksempelvis vil delprøven som kartlegger fonologisk syntese kunne være en god prediktor for vansker, uten at det gir mening å øve på det prøven måler. Mange av elevene som strever med å bli fonemisk bevisste vil først oppdage sammenhengen mellom bokstaver og språklyder når de blir introdusert for bokstavene (Cunningham, 1990). Det er derfor svært uheldig når det rapporteres utstrakt øving på fonologisk syntese uten at elevene samtidig arbeider med bokstaver, med den begrunnelse at dette er en delprøve i kartleggingsprøven for 1. trinn. Øving på fonologiske ferdigheter løsrevet fra arbeid med bokstaver, bokstavmønster og ord er - sammen med tendensen til øving frem mot prøven - 
uheldige praksiser som kaller på et mer funksjonelt prøvedesign som er i stand til å utnytte den tilbakevirkende effekten prøver ofte har på klasseromspraksis (Johnson \& Kress, 2003) til faktisk å lcere å lese. Med andre ord, i et nytt prøvekonsept bør prøvens utforming mer intuitivt styre læreres praksis inn mot kjernen i god leseopplæring: mot selve lesingen.

En tredje utfordring handler om feil bruk av prøveresultater. Fra kartleggingsprøvenes tilblivelse på 90-tallet og frem til i dag har det vært svært utfordrende å kommunisere kartleggingsprøvenes spesifikke formål og begrensninger til lærere - og skoleledere. Det har vært en klar tendens til at formålet tenkes likt som formålet til nasjonale prøver. Til tross for at det i prøvenes veiledninger tydelig fremgår at prøvene skal fungere som et verktøy for å avdekke elever som trenger ekstra hjelp og støtte i leseutviklingen, blir resultatene særlig ofte brukt til å si noe om leseprestasjoner for alle elever i klassen, eksempelvis når alle foreldre i en klasse i foreldrekonferanse får oppgitt sitt barns skåre på kartleggingsprøven. Selve navnet "kartleggingsprøver" må imidlertid også ta sin del av skylden for at hensikten med prøvene har blitt misforstått ved at det leder til en tanke om at prøvene kartlegger de elevene som tar prøven. Faktum er at den gir lite og ingen informasjon av om lag 60-70 \% av elevene. Utstrakt øving på prøvene er et annet eksempel på at formålet med prøvene er misforstått. Det er uvisst om misforståelsen ligger hos læreren selv eller hos en skoleledelse som setter seg mål om hvor få elever man skal ha under bekymringsgrensen, og på den måten utøver uheldig press overfor lærerne, med øving som konsekvens.

Et fjerde punkt gjelder ulik progresjon i opplaringen i første klasse, der elevene blir målt på et fastsatt tidspunkt uavhengig av hvilken progresjon i bokstav- og leseopplæringen det er lagt opp til i undervisningen. Kompetansemål knyttet til lese- og skriveopplæringen er først formulert etter 2. trinn (Kunnskapsdepartementet, 2017). Lærere står fritt til å legge opp til den progresjonen i begynneropplæringen de mener er mest hensiktsmessig for å nå disse kompetansemålene. Basert på en spørreundersøkelse besvart av et stort antall norske lærere rapporterer Rasmussen (2013) om en relativt rask og homogen progresjon i begynneropplæringen, der den store majoriteten har introdusert alle bokstaver før påske i første klasse, men der en mindre andel strekker introduksjonen av bokstavene utover i andre klasse. Dette berører følgelig også prøvenes validitet. Mye tyder på at bokstavprogresjonen fortsatt er i rask endring (Lesesenteret, 2017). Den massive omleggingen til bruk av nettbrett og ny metodikk knyttet til raskere introduksjon av bokstaver skaper trolig ytterligere diversitet mellom ulike praksiser i første klasse, utover de forskjellene i skriftspråklig stimulering elevene har fra hjem og barnehage.

Et femte punkt gjelder en for høy terskel for bruk av prøveresultater. Dette betyr ikke at prøvene er dårlige, men at de krever at brukerne har kompetanse til å omsette prøveresultatene inn mot god praksis. Et godt stykke av veien mellom skåre og tiltak er riktignok dekket i prøvens veiledning. Men når mange lærere 
også rapporterer at de i liten grad bruker denne (Barkved, 2012), blir veien til pedagogisk nytte lang. Samtaler med lærere om kartleggingsprøver viser at lærere ønsker en kortest mulig vei fra prøve til tiltak. Manglende kompetanse og aspekter av å være under oppsyn kan bidra til at prøveresultatene får en uheldig isolert autoritativ status, løsrevet fra prøvens egentlige funksjon. Et nytt prøvekonsept bør derfor rigges optimalt og med alle midler rundt prøvens opprinnelige hensikt.

\section{Denne studien}

Utfordringene ved dagens prøver gir konkrete føringer for hvilke behov en ny prøve må oppfylle. I det følgende undersøker vi muligheten for radikalt å redusere omfanget på prøven ved å se på hvordan førsteklassingers skåre på en setningsleseprøve predikerer de samme elevenes eventuelle vansker med leseforståelse i tredje klasse. Dette har ikke vært mulig å studere før nå, grunnet mangel på longitudinelle data hvor de aktuelle delprøvene i kartleggingsprøven er brukt som mål. Grunnen til dette er at kartleggingsprøvene alene ikke gir god informasjon om alle elevenes leseferdigheter, men kun om de lavest presterende. Prøvene er derfor i liten grad brukt i forsking. I dette prosjektet er den opprinnelige prøven brukt sammen med et tillegg som gjør det mulig å måle alle elevenes ferdigheter, samtidig som man bruker det originale prøveformatet (se Solheim et al., 2018, Lundetræ et al., 2017). Intensjonen med å undersøke førsteklasseprøvens prediksjonsverdi er en ambisjon om tidlig og presist å identifisere de elevene som læreren trenger mer informasjon om for å kunne sette inn tidlige tiltak mot vansker med lesing.

Gjennom å ta utgangspunkt i setningsleseprøven tar vi aspektet fra førstetrinnprøven som i størst grad berører leseforståelse, og ser denne opp mot et mål på leseforståelse i tredjetrinnsprøven. På den måten er det også et forsøk på å aksentuere aspekter av lesing som er i takt med nyere oppfatninger om lesing. Disse nyere oppfatningene av lesing innebærer en bevegelse bort fra et fokus på isolert trening av enkeltkomponenter i leseprosessen, til en oppfatning av lesing som tolkningsferdighet (Tønnessen \& Uppstad, 2015). Dette må ikke misforstås som en bevegelse bort fra delene til fordel for helheten. Tvert i mot er det en understreking av hvor viktige delene er. Poenget er at de ikke må arbeides med isolert; vi må i stedet jobbe med deler og helheter på en integrert måte. Prinsipper til en slik arbeids- og tenkemåte henter vi fra hermeneutikken (Gadamer, 1960; Tønnessen \& Uppstad, 2015).

\section{Metodiske perspektiv}

Datamaterialet i denne studien er del av den randomiserte kontrollerte studien «På sporet» som gjennomføres i regi av Lesesenteret i Stavanger (Lundetræ, Solheim, Schwippert \& Uppstad, 2017). Hovedformålet med På sporet er å bidra 
til å redusere andelen elever som utvikler vansker med lesing og skriving ved å utvikle (i) kartleggingsverktøy som lærere kan bruke for å identifisere risikoelever på et tidlig tidspunkt i opplæringsløpet og (ii) forskningsbaserte tiltak for denne elevgruppa. På sporet-intervensjonen besto av fire ukentlige 45 minutters økter over en periode på 25 uker. Mens intervensjonsopplegget foregikk deltok de resterende elevene i klassene i stasjonsundervisning relatert til lese- og skriveaktiviteter. Intervensjonsgruppene ble ledet av en lærer som hadde fått opplæring i intervensjonsprogrammet. En lærermanual med detaljerte instruksjoner til hver økt ble utviklet som en del av prosjektet. Hver av de 100 intervensjonsøktene bestod av fire ti minutters økter som inkluderte henholdsvis ABC, veiledet lesing, staving og høytlesing. For mer detaljer rundt intervensjonsopplegget se Solheim et al.. (2018).

På sporet-prosjektet følger et stort utvalg elever fra skolestart i 2014 til de har gjennomført nasjonale prøver i lesing på 5. trinn i 2018. Data som rapporteres i denne studien er fra kartleggingen av elevene i april det første året på skolen og i april den våren elevene gikk på tredje trinn. Alle skoler som deltok i prosjektet forpliktet seg til å ha introdusert alle bokstavene for førsteklassingene før påske.

\section{Utvalg}

Utvalget i På sporet-studien er et bekvemmelighetsutvalg, bestående av 19 skoler fra Sør-Vestlandet i relativ nær avstand til Lesesenteret. Totalt 1199 elever startet våren 2014 på de 19 deltakerskolene hvorav 97,7\% prosent av foreldrene ga sitt samtykke til barnets deltagelse. Dette resulterte i et utvalg bestående av 1171 førsteklassinger (50,8\% jenter). $18.6 \%$ av elevene hadde foreldre som snakket et annet språk enn norsk hjemme og $14.1 \%$ hadde en mor eller far som rapporterte å ha lesevansker (Lundetræ et al., 2017). Utvalget ved slutten av 3. klasse besto av et noe lavere antall, 1105 elever, grunnet flytting. En av skolene i utvalget hadde nynorsk som hovedmål, vi valgte å ta denne skolen ut i denne studien og satt dermed igjen med et utvalg på 996 elever.

\section{Prosedyrer og måleinstrumenter}

For å innhente informasjon om elevens leseferdigheter ved utgangen av 1. og 3. trinn ble kartleggingsprøvene i lesing for de respektive trinn benyttet. Prøvene ble gjennomført av forskere fra Lesesenteret i elevenes klasserom. Nedenfor presenteres delprøvene som inngår i kartleggingsprøven for 1 . trinn samt delprøven som måler elevenes leseforståelse i prøven for 3. trinn. Tidsrammen for gjennomføring av kartleggingsprøvene i lesing på alle trinn er 60 minutter.

\section{1. trinn}

Kartleggingsprøven i lesing for 1 . trinn består av følgende delprøver: bokstavkunnskap, posisjonsanalyse, fonologisk syntese, staving, ordlesing og til slutt en prøve som måler elevens evne til å lese og forstå enkle setninger. For å 
sikre at elevene forstår oppgaveformatet blir det gjennomført øvingsoppgaver i forkant av de ordinære oppgaveleddene for hver enkelt delprøve. I tabell 1 gjør vi rede for de statistiske kvalitetene til den enkelte delprøven for utvalget i denne studien.

\section{Bokstavkunnskap}

Denne delprøven retter søkelyset mot elevenes bokstavkunnskap, nærmere bestemt bokstavgjenkalling. Elevene får se et bilde hvorpå de blir bedt om å notere første bokstaven i ordet på bildet i ruten ved siden av bildet. Eksempelvis: "På bildet ser du en bil. Hva er den første bokstaven i ordet bil? Skriv den første bokstaven i ordet bil i ruten ved siden av bildet av bilen."

\section{Fonologisk bevissthet}

To aspekter av elevenes fonologiske bevissthet blir målt gjennom to forskjellige delprøver. I den første delprøven - posisjonsanalyse - leser testleder opp et enkelt lydrett ord samtidig som elevene får se en tegning av ordets betydning. For hver deloppgave blir eleven bedt om å identifisere det første, midterste eller siste fonemet i ordet, for så å skrive den korresponderende bokstaven i ruta ved siden av tegningen. Eksempelvis: «Hvilken lyd kommer sist i ordet by? Skriv bokstaven til siste lyd i ordet by». I den andre delprøven - fonologisk syntese får elevene se fire forskjellige tegninger. Testleder benevner først alle bildene før han så leser opp bokstavlydene i ett av ordene, en bokstavlyd i sekundet. Elevenes oppgave består i å trekke bokstavlydene sammen til et ord og finne frem til bildet som korresponderer med ordet. Eksempelvis: «Her ser dere bilde av en hest - av en hekk - av ei heks - og - av kjeks. Hør godt etter og sett kryss på bildet som passer til h-e-k-s».

\section{Staving}

Delprøven som måler elevenes staveferdighet består av 14 lydrette ord. Lærer leser først en setning og gjentar så ett av ordene i setningen og ber eleven skrive dette. Eksempelvis: «Lise liker is. Is - skriv is».

\section{Ordlesing}

Delprøven «Fra bilde til ord», som ble brukt til å teste elevenes ordlesingsferdigheter, inneholder 14 deloppgaver. Hver deloppgave består av et bilde etterfulgt av fire formlike ord hvorav kun ett korresponderer med bildet (eksempelvis: øks, økt, øke, øse). Elevene blir bedt om å se på bildet, lese ordene og krysse av på ordet som passer best til bildet. Ideen til denne delprøven ble opprinnelig hentet fra Asheims arbeidskort og lesehefter (1981). Elevene får 5 minutter til å jobbe selvstendig med denne delprøven. I ordlesingsprøven er distraktorene (altså svaralternativer som ikke er korrekte) valgt ut med tanke på å gi lærerne informasjon om kilden til problemet for elever som sliter med ordlesing. Ord med semantiske fellestrekk er tatt med for å avsløre eventuelle 
benevningsvansker. Ord som starter med samme stavelse/bokstavsekvens er tatt med for å hjelpe lærer å identifisere elever som sliter med persepsjon av bokstavsekvenser, noe som kan tyde på svikt i den fonologiske strategien. Andre distraktorer kan ha en visuell form som ligner oppgaveordet. Eksempelvis: øks ake, dette for å avsløre elever som gjetter eller leser logografisk.

\section{Setningslesing}

I setningslesingsprøven blir elevene i hver oppgave presentert for en setning bestående av enkle lydrette ord, ledsaget av fire bilder med beslektet innhold. Oppgaven består i å sette kryss på bildet som passer best til setningens betydning. Ideen til denne delprøven er hentet fra de danske leseprøvene SL 60 og SL 40 (Nielsen, Kreiner \& Poulsen, 1986). Elevene får 10 minutter til å lese setningene og svare på oppgavene.

Tabell 1. Beskrivende statistikk for delprøvene: bokstavgjenkalling, posisjonsanalyse, fonologisk syntese, staving, ordlesing og setningslesing i Kartleggingsprøven for 1. trinn (N $=996$ )

\begin{tabular}{lllllll}
\hline Delprøve & $\begin{array}{l}\text { Bokstav- } \\
\text { gjenkalling }\end{array}$ & $\begin{array}{l}\text { Posisjons- } \\
\text { analyse }\end{array}$ & Syntese & Staving & Ordlesing & $\begin{array}{l}\text { Setnings- } \\
\text { lesing }\end{array}$ \\
\hline Antall deloppgaver & 13 & 14 & 12 & 14 & 14 & 10 \\
Gjennomsnitt & 12.54 & 12.66 & 10.28 & 11.09 & 12.10 & 8.71 \\
Standardavvik & 1.38 & 2.30 & 2.06 & 3.45 & 2.73 & 2.35 \\
Min/maks & $0-13$ & $0-14$ & $0-12$ & $0-14$ & $0-14$ & $0-10$ \\
Intern konsistens (Cronbach's & .75 & .79 & .68 & .84 & .74 & .82 \\
alpha) & & & & & & \\
Bekymringsgrense & 12 & 11 & 9 & 8 & 9 & 5 \\
\hline
\end{tabular}

\section{3.trinn}

Kartleggingsprøven i lesing for 3. trinn består av følgende delprøver: Ordlesing, staving, vokabular og leseforståelse. I denne studien er det målet på leseforståelse vi er interessert i.

\section{Leseforståelse.}

Deltesten som måler leseforståelse på 3. trinn består av to tekster. Elevene leser og besvarer flervalgsoppgaver til én faktatekst, «Dyr i ørkenen», og én skjønnlitterær tekst, «Hundevalpen». Før den første delprøven gjennomgår lærer en øvingsoppgave hvor det blir modellert at elevene må bruke teksten for å finne rett svar på oppgavene. I veiledningen til prøven oppgis skårer på 11 eller færre riktige som en bekymringsgrense (i denne studien utgjorde dette 22.9 prosent av elevene, $\mathrm{n}=260$ ). 
Tabell 2. Beskrivende statistikk for delprøven Leseforståelse i Kartleggingsprøven for 3. trinn $(\mathrm{N}=996)$.

\begin{tabular}{|c|c|c|}
\hline Delprøve & & Leseforståelse \\
\hline Antall deloppgaver & & 15 \\
\hline Gjennomsnitt & & 13.04 \\
\hline Standardavvik & & 2.8 \\
\hline Min/maks & & $0 / 15$ \\
\hline $\begin{array}{l}\text { Intern } \\
\text { alpha) }\end{array}$ & (Cronbach's & .74 \\
\hline Bekymringsgrense & & 11 \\
\hline
\end{tabular}

\section{Analyser}

For å undersøke i hvilken grad elevenes skårer på de ulike delprøvene i kartleggingsprøven i lesing for 1 . trinn bidrar til å predikere, eller forutsi, hvorvidt elevene vil skåre under bekymringsgrensen i leseforståelse på 3. trinn, utførte vi en logistisk regresjonsanalyse i SPSS, versjon 25. I en logistisk regresjon har den avhengige variabelen to verdier, i dette tilfellet 0 dersom elevene skåret over bekymringsgrensen i leseforståelse og 1 dersom de skåret under bekymringsgrensen. En odds ratio over 1 betyr økt sannsynlighet for å skåre under bekymringsgrensen, mens en odds ratio under 1 betyr redusert sannsynlighet for å skåre under bekymringsgrensen. Vi vil for eksempel forvente at en høy skåre i ordlesing på første trinn gir redusert sannsynlighet for å skåre under bekymringsgrensen i leseforståelse på 3. trinn (odds ratio $<1$ ). I og med at utvalget inngikk i en intervensjonsstudie, ble det i de logistiske regresjonene kontrollert for hvor vidt elevene hadde mottatt intervensjon. Det ble ikke tatt spesielle hensyn til språklig bakgrunn eller familiær risiko for dysleksi i analysene.

\section{Resultater}

Tabell 3 viser resultater fra logistisk regresjon, med under 20-nde prosentil (altså de $20 \%$ svakest presterende) i leseforståelse på 3. trinn som avhengig variabel. Modellen viser i steg 1 at setningsleseprøven på 1. trinn alene predikerer $24 \%$ av elevene som har vansker med leseforståelse ved utgangen av 3. trinn. I steg 2 ser vi at de de øvrige delprøvene i prøven for 1 . trinn til sammen predikerer ytterligere $0.7 \%$ av elevene som har vansker med leseforståelse to år senere. Modellen har dermed en samlet forklaringskraft på 24.8\%, med setningsleseprøven som klar hovedforklaringskraft. 
Tabell 3. Logistisk regresjon av sammenhengen mellom skårer på kartleggingsprøven på 1 . trinn og skårer under bekymringsgrensen i leseforståelse på 3. trinn ( $\mathrm{n}=996)$.

\begin{tabular}{llllll}
\hline & & $\mathrm{B}$ & SE & OR & 95\% konfidensintervall \\
\hline Steg $1^{\mathrm{a}}$ & Konstant & 0.48 & 0.32 & 1.62 & \\
& Setningslesing & -0.31 & 0.04 & $\mathbf{0 . 7 3}$ & {$[0.69-0.79]$} \\
\hline Steg $2^{\mathrm{b}}$ & Konstant & 1.92 & 0.90 & 6.79 & \\
& Setningslesing & -0.23 & 0.05 & $\mathbf{0 . 7 9}$ & {$[0.72-0.88]$} \\
& Bokstavkunnskap & -0.08 & 0.08 & 0.92 & {$[0.79-1.08]$} \\
& Analyse & -0.02 & 0.06 & 0.98 & {$[0.87-1.10]$} \\
& Syntese & -0.02 & 0.05 & 0.98 & {$[0.89-1.09]$} \\
& Ordlesing & -0.05 & 0.05 & 0.95 & {$[0.86-1.04]$} \\
& Staving & 0.00 & 0.04 & 1.00 & {$[0.92-1.09]$} \\
\hline
\end{tabular}

${ }^{\mathrm{a}}$ Nagelkerke R square $=0.241 .{ }^{\mathrm{b}}$ Nagelkerke R square $=0.248$

Tabell 4 viser korrelasjoner mellom delprøvene i kartleggingsprøven i lesing for første og tredje trinn. Her fremkommer det at setningsleseprøven for 1. trinn viser solid samvariasjon med både leseforståelse, ordlesing og staving på 3. trinn.

Tabell 4. Korrelasjoner mellom delprøver i kartleggingsprøven på 1. trinn og delprøver på 3. trinn $(\mathrm{N}=996)$.

\begin{tabular}{|c|c|c|c|c|c|c|c|c|}
\hline & $\begin{array}{l}\text { Bokstav } \\
1\end{array}$ & $\begin{array}{l}\text { Analyse } \\
1\end{array}$ & $\begin{array}{l}\text { Syntese } \\
1\end{array}$ & $\begin{array}{l}\text { Ordles } \\
1\end{array}$ & $\begin{array}{l}\text { Staving } \\
1\end{array}$ & $\begin{array}{l}\text { Set.les. } \\
1\end{array}$ & $\begin{array}{l}\text { Lesef. } \\
3\end{array}$ & $\begin{array}{l}\text { Ordkjede } \\
3\end{array}$ \\
\hline Bokstav 1 & - & & & & & & & \\
\hline Analyse 1 &, $68 * *$ & - & & & & & & \\
\hline Syntese 1 & $.33 * *$ & $.49 * *$ & - & & & & & \\
\hline Ordles 1 & $.56 * *$ & $.63 * *$ & $.45 * *$ & - & & & & \\
\hline Staving 1 & $.61 * *$ & $.71 * *$ & $.52 * *$ & $.68 * *$ & - & & & \\
\hline Set.les. 1 & $.59 * *$ & $.63^{* *}$ & $.42 * *$ & $.72 * *$ & $.68 * *$ & - & & \\
\hline Lesef. 3 & $.44^{* *}$ & $.46^{* *}$ & $.34 * *$ & $.48 * *$ & $.46^{* *}$ & $.49 * *$ & - & \\
\hline Ordkjede 3 & $.43 * *$ & $.47 * *$ & $.31 * *$ & $.54 * *$ & $.48 * *$ & $.51 * *$ & $.51 * *$ & - \\
\hline Staving 3 & $.45 * *$ & $.49 * *$ & $.39 * *$ & $.50 * *$ & $.57 * *$ & $.51^{* *}$ & $.50 * *$ & $.62 * *$ \\
\hline
\end{tabular}

$1=$ første trinn. 3 = tredje trinn.

Kort oppsummert forteller resultatene at delprøven setningsleseprøven, $\AA$ lese er å forstå, er tilstrekkelig for å predikere vansker med leseforståelse ved utgangen av 3. trinn, dvs. at de øvrige delprøvene i kartleggingsprøven på 1. trinn i liten grad øker presisjonen i prediksjonen av vansker.

\section{Diskusjon}

\section{Å møte utfordringene gjennom en ny prøve}

Vi har over vist hvordan en kort, enkel setningsleseprøve ved slutten av første klasse gir god prediksjonsverdi av vansker med leseforståelse i slutten av tredje klasse. Med utgangspunkt i utfordringene ved dagens prøve som vi skildret 
tidligere i artikkelen, gir dette en god inngang til å forme et nytt prøvekonsept. I vår oppsummering av nevnte utfordringer pekte vi på kombinasjonen av 1) prøvenes omfang, 2) utilsiktede konsekvenser for undervisningspraksis, 3) feil bruk av prøveresultater 4) ulik progresjon og 5) høy terskel for bruk av prøveresultater. Funnet i denne artikkelen gir grunnlag for å diskutere sentrale deler av alle disse utfordringene. Ved å anvende den nevnte setningsleseprøven blir omfanget redusert til om lag en femtedel av tiden, og lesing - som en tolkingsferdighet - blir det sentrale. Ved at en ikke rapporterer enkeltstående komponenter av lesing, vil en redusere faren for at det øves på disse isolert sett (eksempelvis fonologisk syntese) løsrevet fra trening på bokstaver i meningsfulle kontekster. Et nytt prøvekonsept må gi klare føringer for hvordan delene skal inngå i en ny tenkning.

Når det gjelder utfordringen med feil bruk av prøveresultater, vil en enkel prøve bestående av et mål på leseforståelse med dokumentert prediksjonsverdi lettere kommunisere prøvens formål. Det er en utfordring at lærere ofte bruker skårer fra kartleggingsprøver som grunnlag for vurdering av alle elevers ferdighetsnivå. Utfordringen med ulik progresjon i bokstavinnlæringen kan løses ved at prøven gjennomføres etter at elevene har fått introdusert alle bokstaver. Dersom prøven blir frivillig, gir dette lærerne større fleksibilitet til å velge et meningsfylt gjennomføringstidspunkt, det vil si når man har introdusert alle bokstavene. Det er verd å merke seg at den rapporterte prediksjonsverdien som vi presenterer her er fra et utvalg av elever som hadde fått introdusert alle bokstavene før påske i første klasse. Utfordringen med høg terskel for bruk av prøveresultater må løses på flere nivå. Imidlertid, ved å få en enkel prøve med klar prediksjonsverdi for senere vansker med lesing, har vi kommet et langt stykke. Forbedret bruksverdi ligger blant annet i klar longitudinell prediksjon, som grunnlag for tidlige intensive tiltak. Imidlertid vil man kunne innvende at å gjøre prøven kortere vil gi læreren mindre informasjon og kunnskap om eleven. Her er det et poeng at et nytt prøvedesign også må inneholde en del 2 som kommer etter den innledende prøven. I denne må læreren få en type informasjon om elevens lesing som ligger nær lærerens kunnskap om god leseundervisning.

\section{Å bringe prøven i takt med nyere teorier om lesing}

Alexander \& Fox (2004) hevder at forskning på begynneropplæring har blitt hengende igjen i en oppfattelse av lesing som mestring av delferdigheter. De knytter denne tenkningen tett opp til en forståelse av lesing som er sterkt influert av et behavioristisk tankesett hvor det ytre observerbare står i sentrum. Lesing blir i denne tradisjonen studert som tilegnelse av atferd og læring et resultat av gjentatte, kontrollerte stimuli fra omgivelsene og påfølgende forventet respons. I spesialundervisning viser et slikt syn seg i bruk av materiell som legger opp til at elevene skal drilles i delferdigheter, med vekt på automatisering. Innen denne tradisjonen forstås lesing som en kyndig utførelse av en serie beslektede, men likevel adskilte delferdigheter som både kan øves opp og testes separat (Pearson 
\& Stevens, 1994). Denne tenkningen er også utbredt i norsk sammenheng, og særlig én teori har levert premisser for innholdet i begynneropplæring og spesialundervisning i lesing: den fonologiske teorien innenfor rammene av kognitiv psykologi. Den fonologiske teorien ser på lesing som et sett av komponenter som kan trenes isolert, og der visse komponenter må trenes/beherskes før lesing kan skje. Som en utilsiktet konsekvens av dagens prøver blir mange elever sittende å trene på isolerte komponenter i lesing - slik som å lese stavelser - uten at de får eksplisitt instruksjon i hvordan de skal bruke disse ferdighetene når de leser tekster. Det vil være vanskelig å imøtegå en påstand om at dagens praksis i begynneropplæring og spesialundervisning $\mathrm{i}$ lesing er dominert av bruddstykker av denne tenkningen. Nyere teorier om lesing vektlegger bevegelsen inn i - og gjennom - teksten (se Kintsch, 1994; Alexander, 2005; Langer, 2015), med andre ord i lesing som en prosess, en tolkingsferdighet.

Avstanden mellom disse to tankesettene gir en utakt som blir særlig synlig i forbindelse med kartleggingsprøvene uten at utakten nødvendigvis skyldes disse. Denne utakten har bånd til det som i leseforskningslitteraturen noe forenklet er beskrevet som nedenfra-og-opp (bottom-up) vs ovenfra-og-ned (top-down) eller mer karikert som phonics versus whole language (Pressley, 2006). Pressley tar til orde for "a balanced view” ut fra tanken om at både deler og helheter er viktige. Imidlertid gir han få teoretiske bidrag til hvordan dette er mulig, og bare stykkevis når det gjelder hvordan det kan realiseres på et konkret, praktisk plan. Den nevnte utakten mellom de to tankesettene - i brytningen mellom synet på lesing i kartleggingsprøvene og et nyere syn på lesing slik det praktiseres i undervisningen ellers - viser imidlertid at det er vanskelig å skape en funksjonell bro eller dynamikk mellom disse. Med andre ord: lærerne mangler et tankesett for hvordan kombinasjonen av disse arter seg i praksis, og et teoretisk fundament for dette. Utakten forsterkes også ytterligere ved at de to tankesettene langt på veg holdes oppe i to forskjellige tradisjoner, den spesialpedagogiske og den allmennpedagogiske.

En mulig løsning på dette problemet kan imidlertid være å definere lesing som en tolkingsferdighet (Tønnessen \& Uppstad, 2015), en definisjon som også kan fungere som en fellesnevner for nyere oppfatninger om lesing. Her sikter «ferdighet» til den fleksible kombinasjonen av automatikk og oppmerksomhet og «tolking» innebærer at helhet og del kontinuerlig sees i lys av hverandre, som i hermeneutikken (Gadamer, 1960). Tilsvarende kreves ulik grad av oppmerksomhet for å finne meningen i ord og tekstavsnitt. Når lesing på denne måten defineres som en tolkingsferdighet, er det ikke naturlig å skille skarpt mellom avkoding og forståelse. Dette fordi alt fra skrifttegn til dypere mening i en tekst må tolkes, men dette skjer med ulik grad av automatikk og oppmerksomhet. Ettersom «phonics»-tradisjonen primært har fokusert på avkoding, mens «whole language» retningen har lagt størst vekt på forståelse, ser vi at også disse frontene faller hvis vi definerer lesing som en 
tolkingsferdighet. Poenget er altså ikke å ta avstand fra komponentene - eller delene - som inngår i lesingen. Tvert imot er delene avgjørende for lesingen, men på en annen måte enn i den tradisjonelle tenkningen: delene må stadig eksponeres for helhetene, $\mathrm{i}$ en tanke om at det er i denne vekselvirkningen læring og fortolkning skjer (Tønnessen \& Uppstad, 2015). Når «lesing» og leseferdighet i denne tenkningen defineres som en tolkingsferdighet, skiller den seg fra 'leseforståelse' ved at sistnevnte impliserer et produkt av tolkningen, et produkt som imidlertid kan inngå i den videre fortolkningen

\section{Behov for videreutvikling}

Vi har over dokumentert hvordan en enkel setningsleseprøve kan predikere vansker med lesing i tredje klasse. Dette kan ses på som en lovende kime til et nytt prøvedesign - ikke som ferdigstillingen av det. Retningen for det videre arbeidet vil måtte være å få mer informasjon om de elevene som identifiseres som å være i risikosonen for å utvikle vansker. Denne informasjonsinnhentingen må imidlertid gjøres på en måte som holder brukeren av resultatene - læreren - i kontakt med lesingen selv: tolkningsferdigheten. I dagens prøver gis selve skåren en for stor vekt, og der det synes å være et for stort sprang mellom å tolke disse skårene fra prøver gjennomført i gruppe til iverksetting av effektive tiltak. Her er det nok også en gjensidig sammenheng, ved at skåren blir tillagt stor vekt også fordi man ikke forstår den.

Vi foreslår at en andre del av prøven gjennomføres en-til-en, elev-lærer, der mest mulig gjøres for å ta fokus bort fra skåren og over på lærerens observasjon av elevens vansker mens eleven løser oppgavene/leser. Ved å gjøre dette, legger vi til rette for å koble del og helhet (top-down/bottom up) på en annen måte enn før, ved at vi spør: hva det er eleven strever med når hun går frem og tilbake mellom del og helhet?

Som Tveitnes (2018) peker på i samband med PPT, får prøveresultater for ofte en for stor autoritet, uten at resultatet er forstått av den som skal handle. Innholdet i denne andre delen av et nytt prøvedesign kan imidlertid inneholde noen av de samme delprøvene som i det eksisterende designet, i og med at disse er utviklet for å gi detaljert informasjon om de svakeste leserne. Imidlertid, ved at inngangsprøven gjør jobben med identifikasjon, kan del to av prøven derfor fokusere på aspekter ved lesing som lærerne har forutsetninger for å omsette til gode tiltak. De to delene gjør altså to forskjellige oppgaver. Tanken er at med en ny metodikk og filosofi, vil delprøvene i del to få en fornyet funksjon og et klart formål. Den videre prøven kan gjerne utformes som en såkalt adaptiv prøve, og gjennomføres på nettbrett. Gjennomføringen en-til-en gir små eller ingen ekstra kostnader på skolene hva gjelder utstyr (en enhet), og en større såkalt adaptiv prøve ville kunne brukes på første - tredje trinn. En adaptiv prøve tilpasser seg den enkelte elevens ferdighetsnivå, og sørger for at eleven får oppgaver som ikke er for lette men heller ikke for vanskelige. Gjennom dette kan man få maksimalt med informasjon om elevenes ferdighetsnivå, sammenlignet med en 
standard prøve som er lik for alle elevene. Utviklingen av slike prøver krever imidlertid store ressurser.

I denne artikkelen løfter vi således frem behovet for en annen metodikk - og filosofi - for en prøve som har som hensikt å identifisere de som blir hengende etter i lesing. Kort sagt handler metodikken om å gi en screening til alle elever som er så kort og ubetydelig at lærere ikke vurderer det som hensiktsmessig å rapportere skåre til foreldre eller andre. Videre innebærer metodikken å få mer informasjon om bare de elevene som man trenger mer informasjon om, der læreren sitter med eleven en-og-en mens hun løser oppgavene. Dette gir muligheter for å observere lesing som en tolkningsferdighet. En slik ny filosofi innebærer å ta steget bort fra det nakne tallet/skåren som gruppegjennomføringen gir, og over på lærerens forståelse av eleven sine vansker mens eleven løser oppgavene. I tråd med fenomenologisk tenkning ligger det her rom for en annen forståelse, en større helhetsforståelse. Antakelsen er at en slik forståelse kan gi en annen handlingsberedskap for tiltak, og videre for tilpasset opplæring. Kort sagt, ideen er å fjerne så mye som mulig av de uheldige sidene ved den autoritative testen, og samtidig oppvurdere læreren sin dømmekraft.

\section{Konklusjon}

Dagens kartleggingsprøver i lesing ble formet i en tid hvor forskningen var i ferd med å dokumentere at elever som strevde med lesing presterte langt dårligere enn gode lesere på en rekke såkalte komponenter knyttet til leseprosessen, og at tiltak burde fokusere på å øve der hvor vansken var. I et slikt perspektiv får prestasjonene innen de ulike lesekomponentene en egen hensikt; som grunnlag for tiltak. I dag har forskningen ytterligere bekreftet disse karakteristiske forskjellene, men man tenker ikke lenger at tiltakene ensidig bør rettes mot komponentene hvor vanskene viser seg (Scammacca et al., 2007; National Reading Panel, 2000). Utviklingen har gått fra et syn på lesing som summen av et sett komponenter, til et syn på lesing som noe som er mer enn summen av komponentene, til det man kan kalle helhetlige perspektiver på lesing (se for eksempel Tønnessen \& Uppstad, 2015; Alexander, 2005; Langer, 2015). I et slikt perspektiv, blir grunnlaget for tiltak et annet ved at man tar utgangspunkt i fortolkningsprosessen for å bøte på de vanskene som komponentene viser. I nyere definisjoner av lesing er komponenter ikke lenger i sentrum for definisjonen av lesing, men likevel viktige områder for karakteristikk av elever som har vansker med lesing.

Denne studien har hatt som mål å undersøke i hvilken grad komponentene som inngår i dagens kartleggingsprøve er nødvendige for å oppfylle prøvens primære formål: å identifisere de elevene som står i fare for å utvikle lese- og skrivevansker. Dette har vi gjort ved å undersøke hvilke komponenter ved 
dagens prøve som predikerer vansker ved lesing i slutten av tredje trinn. Studien viser at prediksjon er mulig ved kun å bruke en av deltestene ved dagens prøve. I tråd med den beskrevne endringen i synet på lesing, vil en reduksjon av fokuset på komponenter være i tråd med nyere definisjoner på lesing. Et slikt funn vil også ha potensiale for pedagogiske fremskritt, ved å styre læreres oppmerksomhet mot selve leseferdigheten, mot vilkårene for lesing.

\section{Om forfatterne}

Bente Rigmor Walgermo er førsteamanuensis ved Nasjonalt senter for leseopplæring og leseforskning ved Universitet i Stavanger. Hennes forskningsinteresser omfatter blant annet begynneropplæring og motivasjon for lesing, interesse for literacy og tiltro til egne ferdigheter for ulike grupper av lesere.

Institusjonstilknytning: Nasjonalt senter for leseopplæring og leseforskning ved Universitet i Stavanger, Postboks 8600 Forus, 4036 Stavanger.

E-post: bente.r.walgermo@uis.no

Per Henning Uppstad er professor ved Nasjonalt senter for leseopplæring og leseforskning ved Universitet i Stavanger. Hans forskningsinteresser omfatter blant annet intervensjonsforskning, tidlig innsats, lesing og skriving.

Institusjonstilknytning: Nasjonalt senter for leseopplæring og leseforskning ved Universitet i Stavanger, Postboks 8600 Forus, 4036 Stavanger.

E-post: per.h.uppstad@uis.no

Kjersti Lundetræ er førsteamanuensis og leder av Nasjonalt senter for leseopplæring og leseforskning ved Universitet i Stavanger. Hennes forskningsinteresser omfatter blant annet kartlegging av lesing og tidlige tiltak for å fremme leseferdighet og motivasjon for lesing.

Institusjonstilknytning: Nasjonalt senter for leseopplæring og leseforskning ved Universitet i Stavanger, Postboks 8600 Forus, 4036 Stavanger.

E-post: kjersti.lundetre@uis.no

Finn Egil Tønnessen er professor ved Nasjonalt senter for leseopplæring og leseforskning ved Universitet i Stavanger. Hans forskningsinteresser omfatter blant annet lesing, dysleksi, forskningsmetoder og vitenskapsfilosofi.

Institusjonstilknytning: Nasjonalt senter for leseopplæring og leseforskning og ved IGIS, Universitet i Stavanger, Postboks 8600 Forus, 4036 Stavanger.

E-post: finn-egil.tonnessen@uis.no 
Oddny Judith Solheim er førsteamenuensis ved Nasjonalt senter for leseopplæring og leseforskning ved Universitet i Stavanger. Hennes forskningsinteresser omfatter blant annet kartlegging av lesing og tidlige tiltak for å fremme leseferdighet og motivasjon for lesing.

Institusjonstilknytning: Nasjonalt senter for leseopplæring og leseforskning ved Universitet i Stavanger, Postboks 8600 Forus, 4036 Stavanger.

E-post: oddny.j.solheim@uis.no

\section{Referanser}

Alxander, P. A. (2005). The path to competence: A lifespan developmental perspective on reading. Journal of Literacy Research, 37(4), 413-436. doi: 10.1207/s15548430jlr3704_1

Alxander, P. A., \& Fox, E. (2004). A historical perspective on reading research and practice. Theoretical models and processes of reading, 5, 33-68.

Asheim, S. (1981) Ny giv for lesesvake skolebegynnere. Oslo: Universitetsforlaget.

Bakved, E. (2012). Kartlegging av leseferdighet og vurdering for læring. (Masteroppgave). Universitetet i Stavanger, Stavanger. Hentet fra: https://brage.bibsys.no/xmlui/handle/11250/185727

Cuningham, A. (1990). Explicit versus implisitt instruction in phonemic awareness. Journal of experimental child psychology, 50, 56-77. doi: 0.1016/0022-0965(90)90079-N

Ehri, L., Nunes, S. R., Willows, D. M., Schuster, B. V., Yaghoub-Zadeh, Z., \& Shanahan, T. (2001). Phonemic awareness instruction helps children learn to read: Evidence from the National Reading Panel's meta-analysis. Reading Research Quarterly, 36(3), 250-287. doi:10.1598/RRQ.36.3.2

Engen, L. (1999). Kartlegging av leseferdighet på småskoletrinnet og vurdering av faktorer som kan vcre av betydning for optimal leseutvikling: En beskrivelse av den faglige prosessen med å utvikle nasjonale kartleggingsprøver for småskoletrinnet, og en vurdering av forholdet mellom fonologiske delferdigheter, ordlesings -og tekstlesingsferdigheter blant elever i 1. og 2. klasse. (Upublisert Doktorgradsavhandling). Universitetet i Bergen, Bergen.

Gadamer, H. G. (1960). Wahrheit und Methode: Grundziige einer philosophischen. Hermeneutik. Gesammelte Werke J, 5. Tübingen.

Gabrielsen, E., \& Lundetræ, K. (2017). Indikerer de norske PIRLS-resultatene et behov for å justere retningslinjene for skolestartsalder? I Egil Gabrielsen (red.) Klar Framgang. Leseferdighet på 4. og 5.trinn i et femtenårsperspektiv (204-221). Oslo: Universitetsforlaget. doi:10.18261/9788215030258-2017-12

Gustafson, S., Samuelsson, S., \& Rönnberg, J. (2000). Why do some resist phonological intervention? A Swedish longitudinal study of poor readers in grade 4. Scandinavian Journal of Educational Research, 44(2), 145-162. doi:10.1080/713696666

Høien, T. (2012). Håndbok til LOGOS: teoribasert diagnostisering av lesevansker. Bryne: Logometrica (245 s.).

Høien, T., \& Lundberg, I. (1991). Dysleksi. Fra teori til praksis. Oslo: Gyldendal Norsk Forlag A/S.

Johnson, D., \& Kress, G. (2003). Globalisation, literacy and society: Redesigning pedagogy and assessment. Assessment in Education: Principles, Policy \& Practice, 10(1), 5-14. doi:10.1080/09695940301697

Kintsch, W. (1994). Text comprehension, memory, and learning. American 
Psychologist, 49(4), 294. doi:10.1037/0003-066X.49.4.294

Kunnskapsdepartementet (2017). Læreplan i norsk (NOR1-05). Hentet fra: https://www.udir.no/kl06/NOR1-05

Langer, J. A. (2015). Envisioning knowledge: Building literacy in the academic disciplines. Teachers College Press.

Lesesenteret (2017). Førsteklassingene lærer bokstavene raskere. Hentet fra: https://lesesenteret.uis.no/om-lesesenteret/aktuelt/forsteklassingene-larer-bokstaveneraskere-article113370-12719.html

Lundetræ, K., Solheim, O. J., Schwippert, K., \& Uppstad, P. H. (2017). Protocol:’On Track', a group-randomized controlled trial of an early reading intervention. International Journal of Educational Research, 86, 87-95. doi:10.1016/j.ijer.2017.08.011

National Reading Panel. (2000). Teaching children to read: An evidence-based assessment of the scientific research literature on reading and its implications for reading instruction. Washington, DC: National Institute for Child Health and Human Development.

Nielsen, J. C., Kreiner, S., Poulsen, A. \& Søegaard, A. (1986). Scetningslæeseprøverne SL60 og SL40. SL-håndbog. København; Dansk Psykologisk Forlag.

Pearson, P. D. \& Stephens, D. (1994). Learning about Literacy: A 30-Year Journey. I R. B. Ruddel, M.R. Ruddel \& H. Singer (red.), Theoretical Models and Processes of Reading (4. Utgave s. 22-42). Newark DE: International Reading Association

Pressley, M. (2006). Reading instruction that works: The case for balanced teaching (3rd ed.). New York, NY, US: Guilford Press.

Rasmussen, A. (2013). Begynneropplcring i lesing i norske skoler-en undersøkelse av bokstavinnlcering og metodevalg (Masteroppgave). Universitetet i Stavanger, Stavanger. Hentet fra: https://brage.bibsys.no/xmlui/handle/11250/185828

Scammacca, N., Vaughn, S., Roberts, G., Wanzek, J., \& Torgesen, J. K. (2007). Extensive Reading Interventions in Grades K-3: From Research to Practice. Porthsmouth, NH: RMC Research Corperation, Center on Instruction. Hentet fra: http://buildingrti.utexas.org/sites/default/files/booklets/Extensive_Reading_Interventi ons_K-3.pdf

Shaywitz, B. A., Fletcher, J. M., Holahan, J. M., \& Shaywitz, S. E. (1992). Discrepancy compared to low achievement definitions of reading disability: Results from the Connecticut Longitudinal Study. Journal of Learning Disabilities, 25(10), 639-648.

Schneider, W., Roth, E., \& Ennemoser, M. (2000). Training phonological skills and letter knowledge in children at risk for dyslexia: A comparison of three kindergarten intervention programs. Journal of Educational Psychology, 92(2), 284. doi: $10.1177 / 002221949202501003$

Solheim, O.J.; Frijters, J.C.; Lundetræ, K.; Uppstad, P.H. (2018). Efficacy of an early reading intervention in a semi-transparent orthography. A group randomised controlled trial. Learning and Instruction, 58, 65-79. doi:10.1016/j.learninstruc.2018.05.004.

Solheim \& Tønnessen (1998) https://www.regjeringen.no/no/dokumenter/kartlegging-avleseferdighet-og-lesevane/id105518/ lastet ned 13.09.18

Suggate, S. P. (2010). Why what we teach depends on when: Grade and reading intervention modality moderate effect size. Developmental psychology, 46(6), 1556-1579. doi:10.1037/a0020612

Tveitnes, M. S. (2018). Sakkyndighet med mål og mening: En analyse av sakkyndighetens institusjonaliserte kjennetegn; et grunnlag for refleksjon og endring. (Doktorgradsavhandling). Universitetet I Stavanger, Stavanger. Hentet fra: https://brage.bibsys.no/xmlui/handle/11250/2499868

Tønnessen, F. E., \& Uppstad, P. H. (2015). Can We Read Letters? Reflections on Fundamental Issues in Reading and Dyslexia Research. Rotterdam: Sense 
Publishers.

Utdanningsdirektoratet (2018) https://www.udir.no/eksamen-og-prover/prover/hva-erkartleggingsprover/ lastet ned 13.09.18 